\title{
Optimisation of Smart Water to Enhance Oil Recovery Efficiency in a Part of Oil Field of Upper Assam Basin, India
}

\author{
Bhaskarjyoti Saikia, Minati Das
}

\begin{abstract}
Researchers have proved the significance of water injection by tuning its composition and salinity into the reservoir during smart water flooding. Once the smart water invades through the pore spaces, it destabilises crude oil-brine-rock (COBR) that leads to change in wettability of the reservoir rocks. During hydrocarbon accumulation and migration, polar organic compounds were being adsorbed on the rock surface making the reservoir oil/mixed wet in nature. Upon invasion of smart water, due to detachment of polar compounds from the rock surfaces, the wettability changes from oil/mixed wet to water wet thus enhances the oil recovery efficiency. The objective of this paper is to find optimum salinity and ionic composition of the synthetic brines at which maximum oil recovery would be observed. Three core flood studies have been conducted in the laboratory to investigate the effect of pH, composition and salinity of the injected brine over oil recovery. Every time, flooding has been conducted at reservoir formation brine salinity i.e at 1400 ppm followed by different salinities. Here, tertiary mode of flooding has been carried out for two core samples while secondary flooding for one. Results showed maximum oil recovery by $40.12 \%$ of original oil in place (OOIP) at 1050ppm brine salinity at secondary mode of flooding. So, optimized smart water has been proposed with 03 major salts, $\mathrm{KCl}, \mathrm{MgCl}_{2}$ and $\mathrm{CaCl}_{2}$ in secondary mode of flooding that showed maximum oil recovery in terms of original oil in place.
\end{abstract}

Keywords: COBR Interactions, Oil Recovery Efficiency, Polar Compounds, Smart Water, Wettability Alteration

\section{INTRODUCTION}

Smart water (SMW) flooding has drawn attention of new petroleum researchers due to its low cost, environment friendly and consumption of fewer chemicals (Tor Austad, 2012) [1]. Many researchers in their laboratory and field application have found that the COBR equilibrium could be disturbed by tuning the composition and by lowering the salinity of the injected water (Lager et al, 2008a) [2], (Tang and Morrow, 1999a) [3]. In general, water has been considered as the major source of pressure maintenance during secondary recovery. If the same water has been tuned

Revised Manuscript Received on December 30, 2019.

* Correspondence Author

Bhaskarjyoti Saikia*, Department of Petroleum Engineering, DUIET, Dibrugarh University, Dibrugarh-786004, Assam, India.

Email: saikia6894bj@gmail.com

Prof. Minati Das, Department of Petroleum Technology, Dibrugarh University, Dibrugarh, Assam, India, Email: minatidas@dibru.ac.in

(c) The Authors. Published by Blue Eyes Intelligence Engineering and Sciences Publication (BEIESP). This is an open access article under the CC BY-NC-ND license (http://creativecommons.org/licenses/by-nc-nd/4.0/) in terms of composition and salinity, it has become the driving force to change the wettability of the reservoir rock from oil/mixed wet to water wet (Tor Austad, et al., 2010) [4]. During last 15 to 20, researchers have done lots of work on the nature of injected water during SMW flooding and could be able to show positive results over it. Different hypothesis have been put forward in this regard, still having doubt over it.

The nature of the crude oil, composition of reservoir brine and rock type play an important role in altering wettability upon smart water injection. Researchers have found that the chemistry of injected brine is the sole controlling factor which can be optimized during flooding. Since last 20 years, numerous hypothesis have been put forward to support SMW flooding which includes increasing $\mathrm{pH}$, Interfacial Tension (IFT) reduction, Multiple Ion exchange (MIE), in-situ formation of surfactants, clay migration etc. The systematic study on SMW flooding pointed out major prerequisites to be fulfilled during SMW flooding ([3]; Lager et al, 2007 [5]; Lager et al, 2008b [6]) as-

$>$ Porous media: contains clay minerals

$>$ Crude Oil: polar organic compounds must be present.

$>$ Formation brine: Cations must be present, mainly $\mathrm{Ca}^{2+}$ and $\mathrm{Mg}^{2+}$

As mentioned the presence of clay minerals and its texture play an immense role in SMW flooding. Clays are negatively charged in nature and composed of oxides of silicon, aluminium, manganese, iron and are stacked as layers of lamellae in octahedral and tetrahedral textures. So, clays are considered as good ion exchanger that helps in SMW flooding. The relative affinity to the clay surface of cations is referred to as the replacing power of the different cations in solution, which in room temperature is believed to be the following; (Tang and Morrow, 1997 [7])

\section{$\mathrm{Li}^{+}<\mathrm{Na}^{+}<\mathrm{K}^{+}<\mathrm{Mg}^{2+}<\mathrm{Ca}^{2+}<\mathrm{H}^{+}$}

The exchange of cations takes place in the surface of lamellae and creates unbalanced charges during injection of SMW (Buckley J.S, et al., 1989 [8]; Seccombe J et al., 2010 [9]). As a result, an electrical double layer (EDL) is formed near the charged surface of the rock matrix. As soon as the SMW invades the reservoir, the expansion of EDL takes place that sweeps away the mixed wet clays from the clay minerals. Mobilization of mixed wet clay particles enhances the water wetness of the system that results in change in wettability ([9], Rezaiedoust, A, et al., 2010 [10]; Lager et al., 2006 [11])

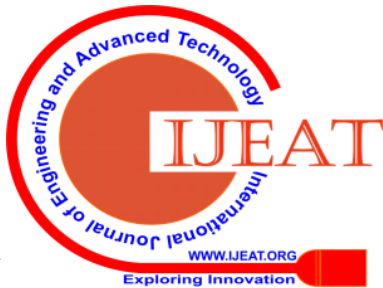


This migration of fines from the clay structure enhances the microscopic sweep efficiency by blocking the pore throats and simultaneously diverting the fluid flow to un-swept areas. An increase in $\mathrm{p}^{\mathrm{H}}$ in imbibitions effluent signifies the desorption of polar organic compounds from the clay surface due to cationic exchange between adsorbed divalent ions (mainly $\mathrm{Ca}^{2+}$ and $\mathrm{Mg}^{2+}$ ) and $\mathrm{H}^{+}$. Crude oils are adsorbed on the clay surface through polar organic compounds as given below:

With basic components:

$\mathrm{R}_{3} \mathrm{NH}^{+}-$Clay $+\mathrm{OH}^{-}=$Clay $+\mathrm{R}_{3} \mathrm{~N}+\mathrm{H}_{2} \mathrm{O}$

With acidic components:

$\mathrm{RCOOH}-\mathrm{Clay}+\mathrm{OH}^{-}=\mathrm{Clay}+\mathrm{RCOO}^{-}+\mathrm{H}_{2} \mathrm{O}$

Desorption of polar compounds are accelerated when the $\mathrm{pH}$ of the injected brine is increased from 5-6 to 8-9. Due to buffering effects in the field situations (mainly presence of $\mathrm{H}_{2} \mathrm{~S}$ and $\mathrm{CO}_{2}$ ), an increase in $\mathrm{p}^{\mathrm{H}}$ phenomena is seldom observed. Parallel to this, increase in $\mathrm{p}^{\mathrm{H}}$ can effectively reduce the affinity between organic compounds and clay minerals, causing the crude oils to desorb from it. Consequently, this leads to change in wettability from oil/mixed wet to water wet.
In this present study, the determination of displacement recovery efficiency has been carried out in core flooding analysis both for secondary and tertiary recovery in a part of oilfield of Upper Assam Basin, India.

\section{METHODOLOGY}

\section{A. Materials:}

A1. Core Materials: In this study, 03 conventional core samples, designated as B1 to B3 have been collected from the Barail formation of the sandstone reservoir of the study area. The depth range of the 03 collected samples is different. The petrophysical properties like porosity (Helium Porosimeter) and permeability (Air permeameter) have been determined before flooding experiments. The liquid permeability has also been calculated from Klingkenberg effect by extrapolating the curves (between reciprocal of average pressure and air permeability). The physical dimension and petrophysical properties are tabulated below in Table- 1 and Table-2 respectively.

Table-1: Physical Dimensions of samples against Depth Range

\begin{tabular}{|c|c|c|c|c|c|}
\hline Sl Nos. & Core Designation & Depth range, $\mathbf{m}$ & Length, $\mathbf{c m}$ & Diameter, $\mathbf{c m}$ & Area, sqcm \\
\hline 1 & B1 & $2707.6-2707.9$ & 7.1 & 3.73 & 10.93 \\
\hline 2 & B2 & $3064.4-3064.8$ & 7.3 & 3.75 & 11.04 \\
\hline 3 & B3 & $3076.2-3076.6$ & 7.1 & 3.71 & 10.08 \\
\hline
\end{tabular}

Table-2: Petrophysical Properties of Core samples

\begin{tabular}{|c|c|c|c|c|c|}
\hline Sl Nos. & Core & Depth range, $\mathbf{m}$ & Porosity, & Air Permeability, md & Liquid permeability, md \\
\hline 1 & B1 & $2707.6-2707.9$ & $25.21 \%$ & 101.85 & 84.48 \\
\hline 2 & B2 & $3064.4-3064.8$ & $22.21 \%$ & 75.41 & 42.85 \\
\hline 3 & B3 & $3076.2-3076.6$ & $18.64 \%$ & 64.92 & 33.43 \\
\hline
\end{tabular}

A2. Crude Oil: Crude oil from the study area has been collected for determination of some important physical properties and core flood analysis. The Acid Number of the sample has been calculated in apparatus, HAMCO-81B. Some other physical properties have been determined in the laboratory and tabulated in Table-3.

Table-3: Physical Properties of Crude oil

\begin{tabular}{|c|l|c|}
\hline SI Nos & \multicolumn{1}{|c|}{ Properties } & Results \\
\hline 2 & API Gravity @ 60 ${ }^{\circ} \mathrm{F}$ & 30.3 \\
\hline 3 & ${\text { Specific Gravity @ } 60^{\circ} \mathrm{F}}$ & 0.8746 \\
\hline 4 & Pour Point, $^{\circ} \mathrm{C}$ & 33 \\
\hline 5 & Acid Number & 0.47 \\
\hline 6 & Wax Content, \% (w/w) & 13.63 \\
\hline
\end{tabular}

\section{B. Brine Preparation:}

B1. Core Cleaning: Here, all the core samples have been cleaned through the distillation extraction process in Sohxlet apparatus. The selectivity of the solvents is dependent on the clay mineralogy. The solvents used in this process are mentioned in Table-4. During core preparation, different physical debris might have contaminated on the core plugs. To ensure complete removal of such debris, presence of any

loose grains which may block the pore spaces, ultrasonic cleaning has been done in Ultrasonic Cleaner for 5 minutes.

Table 4: Solvents used extraction for core cleaning

\begin{tabular}{|c|c|c|c|}
\hline Sl No. & Solvent & \% Quantity & Boiling Point, ${ }^{\mathbf{}} \mathbf{C}$ \\
\hline 1 & Methanol & $20 \%$ & 64.7 \\
\hline 2 & Chloroform & $40 \%$ & 61.2 \\
\hline 3 & Toluene & $40 \%$ & 110.6 \\
\hline
\end{tabular}

Final step of core preparation is Core Drying in Humidity Cabinet. In the present study, the core samples were kept in the humidity oven at $63^{\circ} \mathrm{C}$ and $40 \%$ relative humidity (API-RP-40, 1998 [12]). Total heating period of core plugs was around 42 hours. Time to time, the drying core samples were taken out from the humidity cabinet and weighed till the constant weight was found. The weight of the core samples before after drying was tabulated below in Table-5. 
Table 5: The weight of the core plugs before and after drying in the Humidity Cabinet

\begin{tabular}{|c|c|c|c|c|}
\hline \multirow[t]{2}{*}{ Sl Nos } & \multirow{2}{*}{$\begin{array}{l}\text { Details of Core } \\
\text { Plugs }\end{array}$} & \multicolumn{2}{|c|}{ Weight (gm) } & \multirow{2}{*}{$\begin{array}{l}\text { Difference in weight } \\
\text { (gm) }\end{array}$} \\
\hline & & Before drying & After drying & \\
\hline 1 & B1 & 176.68 & 175.41 & 1.27 \\
\hline 2 & B2 & 176.90 & 174.67 & 2.23 \\
\hline 3 & B3 & 166.66 & 165.69 & 0.97 \\
\hline
\end{tabular}

B2. Preparation of Synthetic formation brine: Synthetic brine at different salinities was prepared in the laboratory by taking the basis of original reservoir formation brine composition and salinity which is 1400ppm.Buckley, J.S. and Morrow, N.R., 1990) pointed out the importance of $\mathrm{Ca}^{2+}$ and $\mathrm{Mg}^{2+}$ ions in SMW flooding as it supports MIE mechanism. $\mathrm{KCl}$ salt acts as clay stabilizer during flooding. Keeping these conditions in mind, the synthetic brines were prepared by considering the important salts like $\mathrm{KCl}, \mathrm{MgCl}_{2}$ and $\mathrm{CaCl}_{2}$.The preparation of synthetic reservoir brine with 1400ppm salinity has been made and tabulated in Table-6

Table6: Ionic concentration and salt composition of synthetic formation brine

\begin{tabular}{|l|l|c|}
\hline \multicolumn{1}{|c|}{ Ions } & \multicolumn{1}{|c|}{ Associated Salts } & $\begin{array}{c}\text { Ions Conc. } \\
\text { (mg/L) }\end{array}$ \\
\hline $\mathrm{K}^{+}$ & $\mathrm{KCl}$ & 591.545 \\
\hline $\mathrm{Na}^{+}$ & $\mathrm{NaCl}$ & 16 \\
\hline $\mathrm{Ca}^{2+}$ & $\mathrm{CaCl}_{2} \cdot 2 \mathrm{H}_{2} \mathrm{O}$ & 6.4 \\
\hline $\mathrm{Mg}^{2+}$ & $\mathrm{MgCl}_{2} \cdot 6 \mathrm{H}_{2} \mathrm{O}$ & 2.4 \\
\hline $\mathrm{SO}_{4}{ }^{2-}$ & $\mathrm{FeSO}_{4} \cdot 7 \mathrm{H}_{2} \mathrm{O}$ & 56 \\
\hline $\mathrm{Fe}^{2+}$ & $\mathrm{FeSO}$ & \\
\hline $\mathrm{Cl}^{-}$ & $\mathrm{HH}_{2} \mathrm{O}$ & 106.12 \\
\hline & $\begin{array}{l}\mathrm{KCl}^{-} \mathrm{NaCl}_{2} \mathrm{CaCl}_{2} \cdot 2 \mathrm{H}_{2} \mathrm{O}, \\
\mathrm{MgCl}_{2} \cdot 6 \mathrm{H}_{2} \mathrm{O}\end{array}$ & 621.535 \\
\hline \multicolumn{2}{|c|}{ Salinity } & $\mathbf{1 4 0 0}$ \\
\hline
\end{tabular}

\section{B3.Core Flooding Experiments:}

B3.1: Determination of connate water saturation: Dry and clean core plug has been put into the Hassler Core Holder. Around $500 \mathrm{ml}$ of synthetic formation brine having salinity $1400 \mathrm{ppm}$ was put in cylinder-I while $500 \mathrm{ml}$ of crude oil containing $5.75 \%(\mathrm{w} / \mathrm{w})$ resins and $0.10 \%(\mathrm{w} / \mathrm{w})$ asphaltenes in cylinder-II. Pore volume of the core plug has been calculated. A total of 20 pore volumes (PV) have been flooded so that the core plug got fully saturated with 1400ppm of synthetic formation brine. Next flooding has been followed by with crude oil at the same flow rate for 20 PV. Flooding continued till last volume of water traced in the effluent. From the actual water coming out from the core plugs (after subtracting line volume), connate water saturation $\left(\mathrm{S}_{\mathrm{wc}}\right)$ has been determined. Ageing of core plug has been done for 14 days in the core holder with a confining pressure of 200psi to facilitate crude, brine and rock to equilibrate. All the flooding operations have been conducted at room temperatures. The following table shows the value of connate water saturation $\left(\mathrm{S}_{\mathrm{wc}}\right)$ with respect to corresponding pore volume and ageing time.

Table-7: Determination of Connate Water Saturation for all Core plugs

\begin{tabular}{|c|c|l|l|c|}
\hline $\begin{array}{l}\text { Sl } \\
\text { Nos. }\end{array}$ & $\begin{array}{l}\text { Core } \\
\text { Nos. }\end{array}$ & $\begin{array}{l}\text { Pore } \\
\text { Volume }\end{array}$ & $\begin{array}{l}\text { Ageing } \\
\text { Time }\end{array}$ & $\begin{array}{l}\text { Connate Water } \\
\text { Saturation, Swc }\end{array}$ \\
\hline 1 & B-1 & 14.39 cc & 14 Days & $26.89 \%$ \\
\hline 2 & B-2 & 13.74 cc & 18 Days & $30.71 \%$ \\
\hline 3 & B-3 & 17.19 cc & 21 Days & $28.53 \%$ \\
\hline
\end{tabular}

B.3.2 Tertiary mode of flooding (Sample B\#1): Here, reservoir formation brine (FB) salinity i.e. 1400ppm has been considered as the high salinity brine. Aged core sample (B-1) was flooded for $20 \mathrm{PV}$ with $1400 \mathrm{ppm}$ synthetic FB consisting of important salts like $\mathrm{KCl}, \mathrm{MgCl}_{2}$ and $\mathrm{CaCl}_{2}$. Oil recovery efficiency has been measured from the actual oil recovery data obtained from the graduated glass tube. For all the flooding operations, $\mathrm{P}^{\mathrm{H}}$ has been measured for synthetic formation brine and the recovered effluents. With the help of oil recovery data, residual oil saturation (ROS) has been measured and tabulated in table-8. It has been observed that the oil recovery efficiency has been found as $30.82 \%$ by flooding with synthetic formation brine having 1400ppm salinity. All the experimental data has been tabulated in table-8. The flooded core plugs (B-1) has been further flooded with low salinity brine with 1200ppm followed by $1050 \mathrm{ppm}$ in tertiary mode. In 1200ppm flooding experiment, no oil recovery has been observed. While flooding with $1050 \mathrm{ppm}$, extra oil recovery of $6.45 \%$ has been noticed. For both the experiments, 10PV brine has been injected in each case at room temperature. Here, overall oil recovery was found to be $37.27 \%$ of OOIP. 


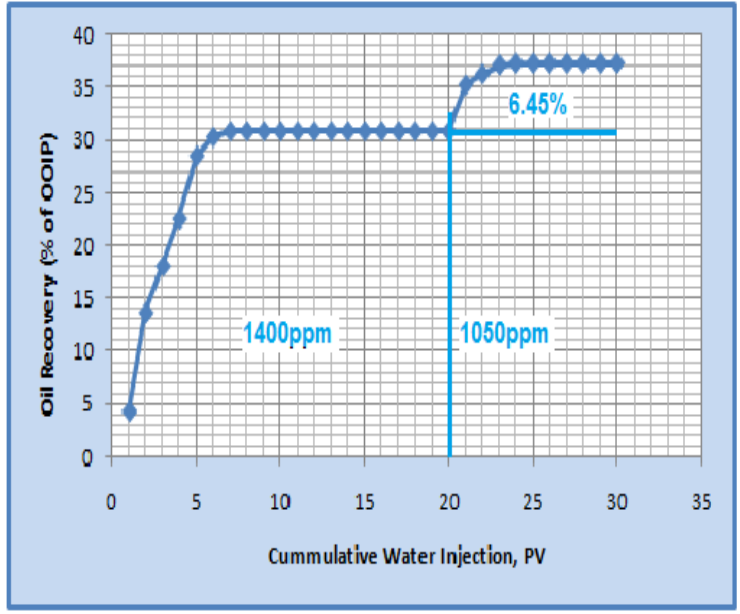

Fig 1.1: OIL RECOVERY AT 1050PPM

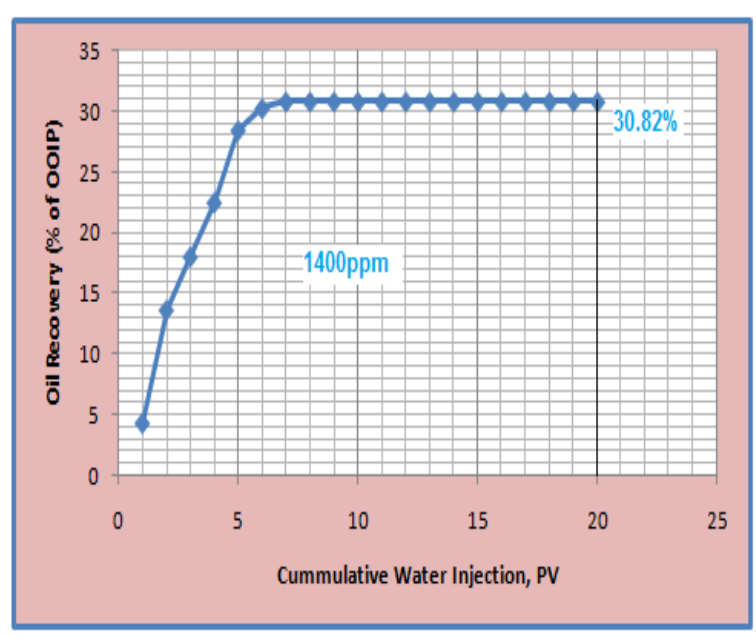

Fig 1.2: OIL RECOVERY AT 1400PPM BRINE

Table 8: Experimental flooding data for Core Plugs, B-1 in Tertiary mode

\begin{tabular}{|c|c|c|c|l|}
\hline Core & $\begin{array}{c}\text { Residual Oil } \\
\text { Saturation (ROS) }\end{array}$ & $\begin{array}{c}\text { Nature of } \\
\text { Brine }\end{array}$ & $\begin{array}{c}\text { Synthetic brine } \\
\text { salinity, ppm }\end{array}$ & \multicolumn{1}{|c|}{$\begin{array}{c}\text { Oil Recovery Efficiency } \\
\text { (\% of OOIP) }\end{array}$} \\
\hline B-1 & \multirow{2}{*}{$51.01 \%$} & HSW & $1400 \mathrm{ppm}$ & $30.82 \%$ \\
\hline B-1 & & LSW & $1200 \mathrm{ppm}$ & No Extra Recovery \\
\cline { 3 - 5 } B-1 & & LSW & $1050 \mathrm{ppm}$ & $\begin{array}{l}\text { Total recovery }=37.27 \% \\
\text { Additional recovery }=6.45 \%\end{array}$ \\
\hline
\end{tabular}

B.3.3: Secondary Mode of Flooding (Sample B\#2): As from previous tertiary core flooding experiment, the salinity (1050ppm) showed satisfactory additional recovery. Now considering the same brine salinity, secondary flooding has been performed by taking the same salt composition. In this secondary experiment, the saturated core sample (B-2) was being flooded with 1050ppm of synthetic brine. A total of 20PV has been flooded at room temperature to mark the oil recovery. The total oil recovery of $40.12 \%$ has been observed. The experimental results are tabulated in Table- 11 . B.3.4: Tertiary mode of flooding (Sample B\#3): The saturated core plug (B-3) has been flooded with series of synthetic brine from HSW to very LSW brine (400ppm) to check the effect of LSW of oil recovery. Here also, reservoir FB salinity (1400ppm) has been taken as HSW brine and the flooding pattern been followed by LSW brine having salinities 1200ppm, 1050ppm, 850ppm and 400ppm. Core plug has been flooded for 20PV for HSW brine, 10PV each for $1200 \mathrm{PV}$ and $1050 \mathrm{ppm}$ and finally 5PV each for $850 \mathrm{ppm}$ and 400PV. No additional recovery has been observed for $1200 \mathrm{ppm}, 850 \mathrm{ppm}$ and 400ppm salinity brine. Oil recovery of $30.61 \%$ has been collected by $1400 \mathrm{ppm}$ brine while additional recovery has been observed only by $1050 \mathrm{ppm}$ as $5.8 \%$. The cumulative oil recovery has been calculated as $36.41 \%$. The experimental results are tabulated in Table- 11 .
The $\mathrm{p}^{\mathrm{H}}$ value of the injected synthetic brine as well as the flooding effluent has been determined for all the cases of flooding and tabulated in Table-12. Slight increase in $\mathrm{p}^{\mathrm{H}}$ has been observed in all the flooding experiments.

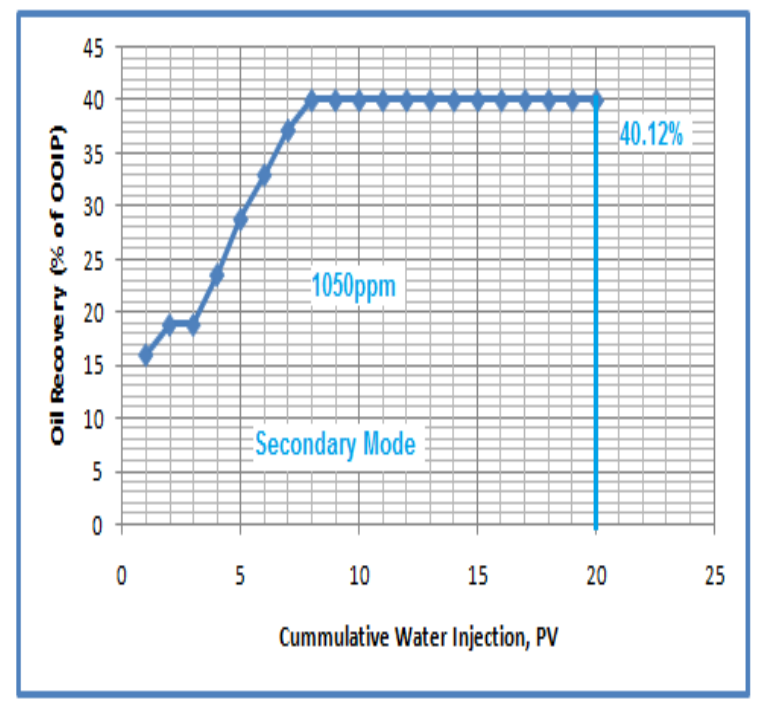

Fig1.3: Oil recovery at secondary mode(1050ppm) 


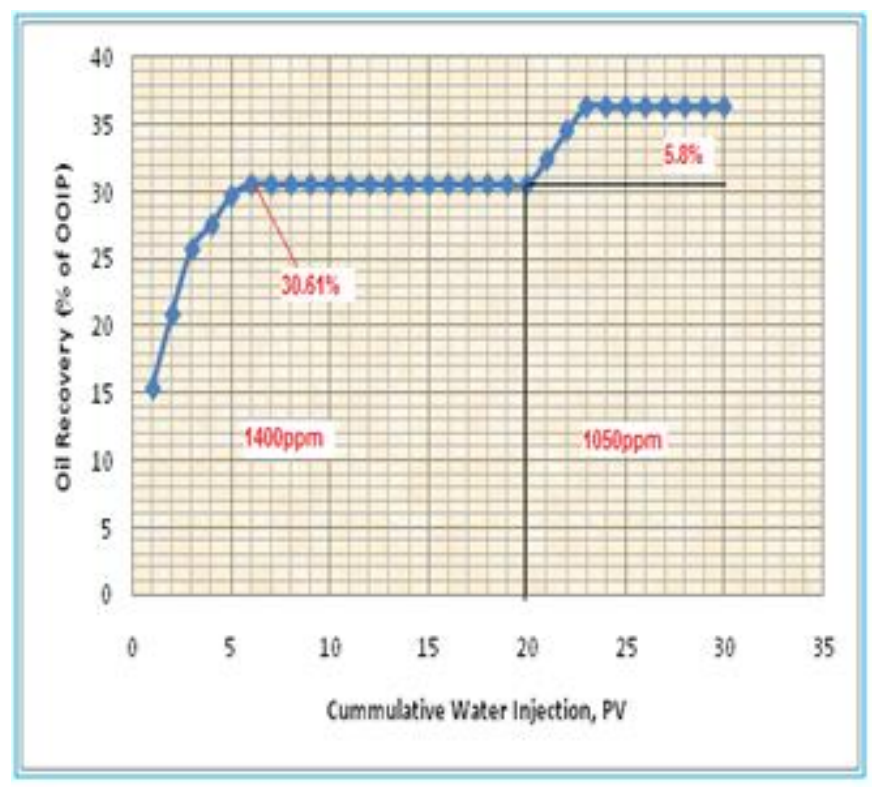

Fig 1.4: Additional oil recovery at tertiary mode (Sample: B\#3)

Table-9: Experimental results for Secondary/Tertiary mode of flooding for sample B\#1 and B\#2

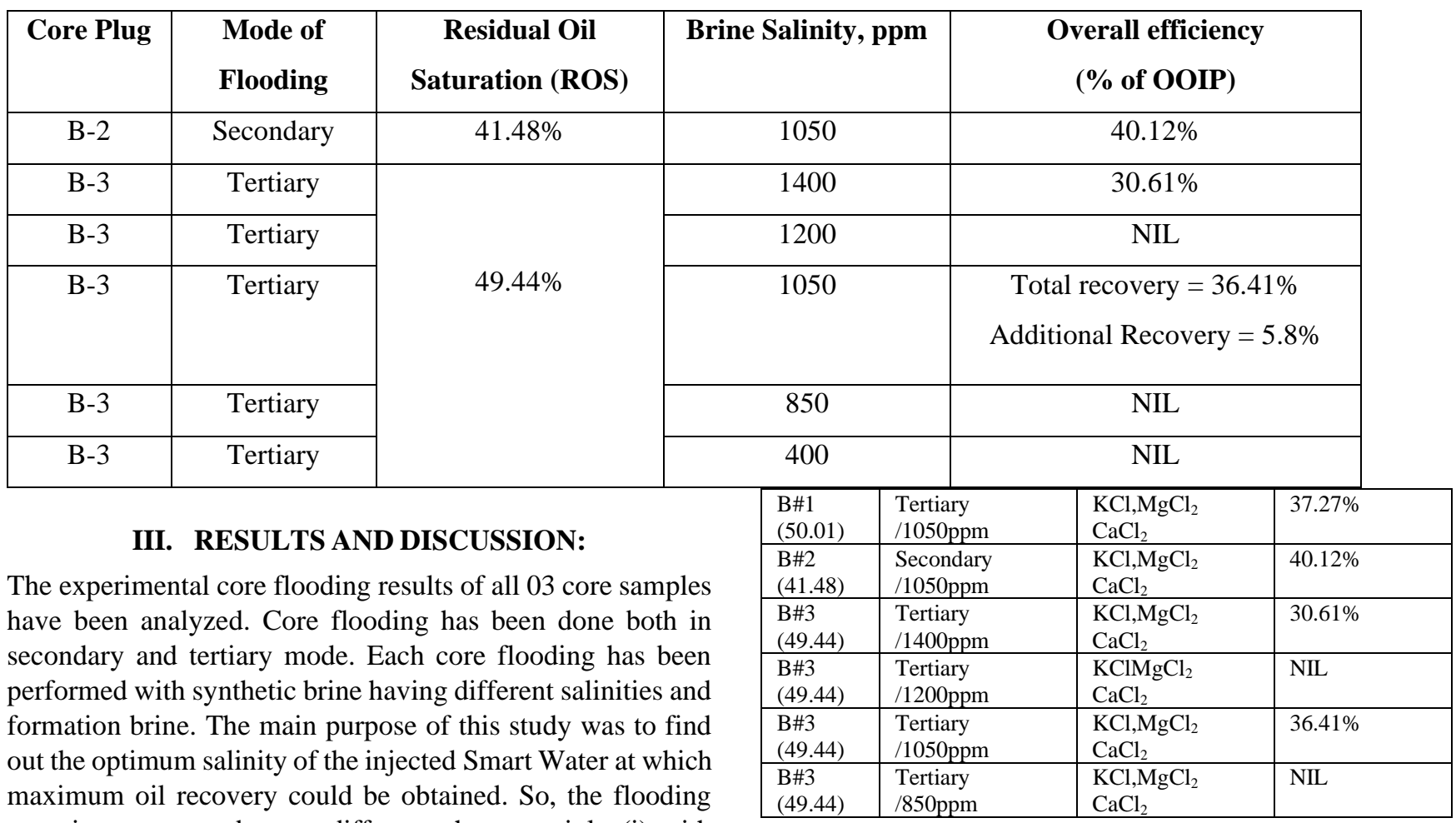
experiments were done at different phases mainly (i) with synthetic formation brine (ii) with HSW followed by LSW in tertiary mode and (iii) with secondary mode. All the experimental data were compared for secondary and tertiary mode of flooding. Instead of considering all the salts, only 03 essential salts have been considered, mainly $\mathrm{KCl}$ (acts as clay stabilizer), $\mathrm{MgCl}_{2}$ and $\mathrm{CaCl}_{2}$ (take part in cation exchange during flooding). The following table shows the core flooding results at different brine salinities.

Table10: Results of Core Flooding Experiments

\begin{tabular}{|l|l|l|l|}
\hline $\begin{array}{l}\text { Sample } \\
\text { (ROS) }\end{array}$ & $\begin{array}{l}\text { Flooding } \\
\text { mode/Salinity }\end{array}$ & $\begin{array}{l}\text { Salt } \\
\text { Composition }\end{array}$ & $\begin{array}{l}\text { Recovery } \\
\text { Efficiency }\end{array}$ \\
\hline $\begin{array}{l}\mathrm{B} \# 1 \\
(50.01)\end{array}$ & $\begin{array}{l}\text { Tertiary } \\
/ 1400 p p m\end{array}$ & $\begin{array}{l}\mathrm{KCl}, \mathrm{MgCl}_{2} \\
\mathrm{CaCl}_{2}\end{array}$ & $30.82 \%$ \\
\hline $\mathrm{B} \# 1$ & Tertiary & $\mathrm{KCl}, \mathrm{MgCl}_{2}$ & $\mathrm{NIL}$ \\
$(50.01)$ & $/ 1200 \mathrm{ppm}$ & $\mathrm{CaCl}_{2}$ & \\
\hline
\end{tabular}


(i) Oil recovery efficiency for core sample nos. B\#1 was found to be $30.82 \%$ at $1400 \mathrm{ppm}$ salinity. No additional recovery has been observed at $1200 \mathrm{ppm}$ salinity brine. As it followed tertiary mode of flooding, finally the same core sample has been flooded with 1050ppm salinity brine and additional recovery of $6.45 \%$ has been observed. The total oil recovery efficiency was found for the sample B\#1 was $37.27 \%$. For preparation of all salinity brine, three salts mainly $\mathrm{KCl}, \mathrm{MgCl}_{2}$ and $\mathrm{CaCl}_{2}$ have been used. As mentioned earlier, $\mathrm{KCl}$ has been used as clay stabilisation for the experiment which prevents clay swelling.

(ii) For sample B\#2, secondary mode of flooding has been followed with the same brine composition as mentioned for the sample B\#1. Here, $40.12 \%$ total oil recovery has been observed by flooding the core sample with 1050ppm salinity brine. Only synthetic brine with 1050ppm has been used, not followed by any other brine due to secondary mode of flooding.

(iii) As the sample B\#3 followed tertiary mode of flooding, the invaded brine pattern was 1400ppm, 1200ppm, 1050ppm and lastly $850 \mathrm{ppm}$ synthetic brine. The oil recovery efficiency was found highest at $1050 \mathrm{ppm}$ salinity brine with $36.41 \%$. Additional oil recovery has been observed with $5.8 \%$ with comparison to $1400 \mathrm{ppm}$. No additional recovery has been found at salinities for 1200ppm and 850ppm.

Earlier researchers have put numerous hypotheses that support SMW flooding ([4], [7], Skauge A. et al, 1999 [14], (Ligthelm, D.J et al, 2009 [15]). Change in $\mathrm{pH}$ of the flooding brine is one of the outcomes of such mechanism. It was postulated that during accumulation and migration of hydrocarbons, there had been developed strong equilibrium between crude oil-rock and brine (COBR) and made the reservoir oil/mixed wet ([4] - [7]). Once SMW invades the reservoir, $\mathrm{pH}$ of the formation brine changes which enhances the detachment of polar organic compounds from the clay surfaces. So, increase in $\mathrm{pH}$ has a link with detachment of polar compounds thus enhancement in oil recovery efficiency. The following table shows the $\mathrm{pH}$ value of the injected flooded brine as well as the effluent brine

Table 11: pH of injected/effluent brine during flooding

\begin{tabular}{|c|c|c|c|}
\hline Sample & $\begin{array}{l}\text { Flooding Mode } \\
\text { / Salinity(ppm) }\end{array}$ & $\begin{array}{l}\mathrm{pH} \text { brine injected } \\
\text { be }\end{array}$ & $\begin{array}{l}\mathrm{pH} \text {, effluent } \\
\text { brine }\end{array}$ \\
\hline B-1 & Tertiary/1400 & 6.54 & 6.59 \\
\hline B-1 & Tertiary/1200 & 6.62 & 6.65 \\
\hline B-1 & Tertiary/1050 & 6.21 & 6.30 \\
\hline B-2 & Secondary/1050 & 6.21 & 6.38 \\
\hline B-3 & Tertiary/1400 & 6.54 & 6.61 \\
\hline B-3 & Tertiary/1200 & 6.21 & 6.29 \\
\hline B-3 & Tertiary/1050 & 6.18 & 6.75 \\
\hline B-3 & Tertiary/850 & 6.31 & 6.38 \\
\hline
\end{tabular}

(iv)From the post flooding calculation in terms of $\mathrm{pH}$ measurement, it has been observed that for all the experiments, increase in $\mathrm{pH}$ in the effluent happened to some extent. Out of all the flooding experiments, it has been seen that change in $\mathrm{pH}$ value for sample $\mathrm{B} \# 1$ for secondary mode of flooding having 1050ppm salinity is more. This implies positive response has been considered for incremental oil recovery at $1050 \mathrm{ppm}$ at secondary mode

Presence of polar organic compounds in crude oil is an essential prerequisite for SMW flooding. To establish initial wetting condition, the determination of polar organic compounds has been performed in the laboratory to ensure presence of resin and asphaltene contents. The following table shows the results obtained for analysis of crude oil for polar compounds in it.

Table12: Results of Polar compounds in crude oil

\begin{tabular}{|l|l|l|l|}
\hline $\begin{array}{l}\text { Sl } \\
\text { Nos. }\end{array}$ & $\begin{array}{l}\text { Crude oil } \\
\text { Type }\end{array}$ & Properties & Results \\
\hline 1 & C & Acid Number & 0.47 \\
\hline 2 & C & Resin (w/w, \%) & $5.75 \%$ \\
\hline 3 & C & $\begin{array}{l}\text { Asphaltene (w/w } \\
\%)\end{array}$ & $0.10 \%$ \\
\hline
\end{tabular}

(v)It has been observed that the polar organic concentration in crude oil of the study area contained resin 5.75\%, w/w and $0.10 \% \mathrm{w} / \mathrm{w}$. As stated, presence of such compounds in the flooded crude implies positive response to the experiments. The presence of polar compounds in crude oil changes the wettability of the reservoir rock to oil wet during accumulation and migration of crude oil. Crude oils are adsorbed on the clay minerals and changed the wettability to oil wet. During SMW flooding, polar compounds are desorbed from the clay surfaces and made the reservoir water wet, hence increases the oil recovery efficiency.

(vi)As three major prerequisite salts were used for preparation of synthetic formation brine (1400ppm) as well as other injected synthetic brine having salinities $1200 \mathrm{ppm}$, $1050 \mathrm{ppm}, 850 \mathrm{ppm}$ and 450ppm. The salts were $\mathrm{KCl}, \mathrm{MgCl}_{2}$ and $\mathrm{CaCl}_{2}$ where the role of $\mathrm{KCl}$ was to stabilize clay swelling during hydration of clay minerals. The other two salts acted as cation exchange $\left(\mathrm{Ca}^{2+}\right.$ and $\left.\mathrm{Mg}^{2+}\right)$ during SMW flooding.

\section{CONCLUSION}

From the experiments and the results, it can be concluded that oil recovery has been calculated in terms of original oil in place (OOIP) with respect to injected pore volume (PV). Recovery of $30.82 \%$ with additional $6.45 \%$ (Cumulative oil recovery of $37.27 \%$ ) has been determined for sample no B\#1 while $36.41 \%$ with additional recovery (cumulative $36.41 \%$ ) has been recovered for sample B\#3. Both the experiments have been conducted for tertiary mode of flooding. But highest oil recovery has been observed for sample B\#2 with oil recovery of $40.12 \%$ in secondary mode of flooding. So, the final optimized smart water can be proposed at 1050ppm salinity brine with $\mathrm{KCl}, \mathrm{MgCl}_{2}$ and $\mathrm{CaCl}_{2}$ at secondary mode of flooding. 


\section{ACKNOWLEDGMENT}

The authors are thankful to OIL, Duliajan for providing conventional core samples of the study area, for analysis of crude oil and formation brine. The authors also extend their thanks to the department of Petroleum Technology, Dibrugarh University for carrying out Petrophysical properties of rock samples. Authors are thankful to the Department of Applied Geology, Sophisticated Central Laboratory, Dibrugarh University for providing support to carry Petrograhic analysis.

\section{REFERENCES}

1. 1.Austad, Tor (2012): "Water Based EOR in Carbonates and Sandstones: New Chemical Understanding of the EOR-Potential Using "Smart Water", Muscat, April, 2012, University of Stavanger, Norway, 4036 Stavanger, Elsevier, 2012.

2. 2.A. Lager, K. J. Webb, I. R. Collins, and D. M. Richmond: "LoSal enhanced oil recovery: Evidence of Enhanced Oil Recovery at the Reservoir Scale," in Proceedings of the SPE Symposium on Improved Oil Recovery, SPE-113976-MS, Tulsa, Okla, USA, April, 2008a.

3. Tang, G.Q and Morrow, N.R. (1999a): 'Oil Recovery by Waterflooding and Imbibition -Invading Brine Cation Valency and Salinity', Paper SCA-9911 presented at the 1999 International Symposium of the Society of Core Analysts, Colorado, USA, 1-4 August, 1999.

4. Austad T., Rezaei Doust A., and Puntervold T. (2010): "Chemical Mechanism of Low Salinity Water Flooding in Sandstone Reservoirs,' Paper SPE 129767-PP. Presented at the 2010 SPE Improved Oil Recovery Symposium, Tulsa.

5. Lager, A., Webb, K., and Black, C. (2007): 'Impact of Brine Chemistry on Oil Recovery', $14^{\text {th }}$ European Symposium on IOR, 2007.

6. Lager, A., Webb, K., J. Black, C., Singleton, M., and Sorbie, K. (2008b): 'Low Salinity Oil Recovery-An Experimental Investigation', Petrophysics, 49(1), pp.1-10.

7. Tang, G.Q., Morrow, N.R (1997): 'Salinity, Temperature, Oil Composition and Oil Recovery by Waterflooding', SPE Reservoir Engineering, 1997.

8. Buckley J. S., Takamura K and Morrow N.R (1989): 'Influence of Electrical Surface Charges on the Wetting Properties of Crude Oils', SPE Reservoir Engineering, Vol(4), pp. 333-339.

9. Seccombe, J., Lager, A., Jerauld, G., Jhaveri, B., Buikema, T., Bassler, S., Denis, J., Webb,K., Cockin, A., Fueg, E. and Paskvan, F., (2010): 'Demonstration of low-Salinity EOR at interwell scale, Endicott field, Alaska', Paper SPE 129692 presented at the 2010 SPE Improved Oil Recovery Symposium, 24 - 28 April,2010.

10. Rezaiedoust A., Austad T., Puntervold T. (2010): 'Chemical Mechanism of Low Salinity Water Flooding in Sandstone Reservoirs', Paper SPE 129767-pp presented at the 2010 SPE IOR Symposium held at Tulsa, Oklahama, USA, 24 -28 April, 2010.

11. 11.A. Lager, K. J. Webb, C. J. J. Black, M. Singleton , K. S. Sorbie., (2006): 'Low Salinity Oil Recovery - An Experimental Investigation', International Symposium of the Society of Core Analysts, Institute of Petroleum Engineering, Herriot-Watt University, Research Park, Riccarton, Edinburgh EH14 4AS, UK, pp. 3-11, 12-16 September, 2006.

12. 12.API RP 40(1998): "Recommended Practices for Core Analysis", American Petroleum Institute, Second Edition, pp: 2 /14-18, February, 1998.

13. 13.Buckley, J.S. and Morrow, N.R. (1990): "Characterization of Crude Oil Wetting Behaviour by Adhesion Tests," Paper SPE 20263 presented at the 1990 SPEIDOE Symposium on Enhanced Oil Recovery, Tulsa, 1990, April 22-25.

14. 14.Skauge A., Standal S., Boe S.O., Skauge T. And Blokhus A.M. (1999): 'Effects of Organic Acids and Bases, and oil composition on Wettablility,' SPE Annual Technical Conference and Exhibition. Society of Petroleum Engineers 56673, Houston, Texas, pp. 102-110.

15. 15.Ligthelm, D.J., Gronsveld, J., Hofman, J.P., Brussee, N.J., Marcelis, F. and Linde, H.A., (2009): 'Novel waterflooding strategy by manipulation of injection brine composition', Paper SPE 119835 presented at the 2009 SPE EUROPEC/EAGE Annual conference and exhibition, 8-11 June, 2009.

\section{AUTHORS PROFILE}

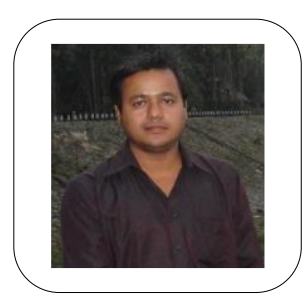

Mr. Bhaskarjyoti Saikia is an assistant professor in the department of Petroleum Engineering, Dibrugarh University Institute of Engineering and Technology, DUIET, Dibrugarh University. He received his B.Tech degree in Chemical Engineering from Assam Engineering College, Gauhati and M.Tech from Dibrugarh University. His area of specialization is Petroleum Refining and Petrochemicals. Presently, he is pursuing Ph.D in Petroleum Technology department, Dibrugarh University. He worked as research assistant in TIFAC-Centre of Excellence (CORE) project Under DST, Govt of India for the period of year 2004-2006. He was awarded Prof. J.S.R. Krishna Rao, Dr. R. Dhana Raju, medal for the best paper published in the "Journal of Applied Geochemistry" (ISAG) for the year 2007. He has also been awarded for best presentation in National Conference in Upstream Petroleum Engineering (NCUPE, 2019) in IIT, Guwahati on $3^{\text {rd }}$ November, 2019. He has 7 years of industrial experience in Brahmaputra Valley Fertilizer and Corporation Limited, BVFCL (a central PSU under ministry of chemicals and fertilizer, Govt of India) as management trainee, assistant engineer and assistant plant manager.

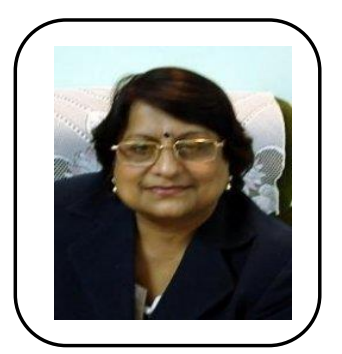

Dr. Minati Das is a Professor and Head in the Department of Petroleum Technology, Dibrugarh University. She received her Ph.D. in Petroleum Technology. She has six years of industrial experience in Oil \& Natural Gas Corporation Ltd. as Reservoir Engineer and Assistant Director (Reservoir); and thirty two years of postgraduate teaching experiences (reservoir engineering) in the Department of Petroleum Technology. She is the member of editorial Board in national \& international journal. She has published more than fifty number of research papers in national, international journal \& proceeding volume. She received Prof. J.S.R. Krishna Rao, Dr. R. Dhana Raju, medal for the best paper published in the "Journal of Applied Geochemistry" (ISAG) for the year 2007. Her research area of interest is in Petroleum Geology and Reservoir Engineering. She has established a Centre of Excellence (CORE) in the Department of Petroleum Technology in Clastic Petroleum Reservoir Engineering under Mission REACH (Relevance \& Excellence in Achieving New Heights in Educational Institutions), TIFAC(Technology Information Forecasting and Assessment council), under Department of Science and Technology, Govt. of India. 